\title{
Employee Readiness for Organizational Change: A Case Study in an Export Oriented Manufacturing Firm in Sri Lanka
}

\author{
Sanjee Udari SAMARANAYAKE ${ }^{*}$, Toshihiko TAKEMURA**
}

Received: February 5, 2017 Revised: August 30, 2017 Accepted: September 4, 2017

\begin{abstract}
In this article, we investigated the relationships between organizational commitment, trust in peers and management and employee change readiness. The effects of demographic factors such as gender, age, and working experience on employees' organizational commitment, trust in peers and management and their change readiness were also examined. We conducted a cross sectional questionnaire survey to collect data from a sample of 185 randomly selected employees in an export oriented business firm in Sri Lanka. Pearson Productmoment Correlation test was used to test the strength and direction of the relationships in the hypotheses. A Multiple analysis of variance (MANOVA) was employed to analyse the relationships between demographic variables and the three main variables concerned. This article unveiled that organizational commitment and trust in peers and management were significantly and positively correlated to employee readiness for organizational change. The article also revealed the significant association of certain demographic factors with trust in peers and management and employee readiness.
\end{abstract}

Keywords: Employee readiness, Organizational change, Organizational commitment, Trust in peers and management, Demographical factors

JEL Code Classification: L2

UDC: 005.7

DOI: https://doi.org/10.17015/ejbe.2017.020.01

\footnotetext{
Graduate School of Science and Engineering, Saga University, Saga, Japan.

E-mail: ssudari.uop@gmail.com

${ }^{* *}$ Associate Professor, Faculty of Economics, Saga University, Saga, Japan.

E-mail: tosihiko@cc.saga-u.ac.jp

Copyright @ , 2017 Ala-Too International University.
} 


\section{Introduction}

Globalization and rapid advancement in technology has turned the entire world in to a highly competitive and ever-changing market place. Therefore, business organizations must embrace change to survive and prosper in a highly competitive and volatile business environment. On the other hand, eliciting, implementing and managing changes within business organizations are challenging and time consuming. To adapt to changes demanded by the business environment, a firm may have to implement a planned change process in which the employees' role would be highly decisive. For example, Ghany (2014) reports that managing organizational change is in very large part, about managing the people. However, employees may not welcome such changes instantly or without being pushed through a strenuous change programme.

A change process can deliver successful results only at the places where employees could change their mind set to welcome the change (Ragadu, 2008) and where employees could accept the change in a positive manner (Lazenby \& Radebe, 2011). Therefore, employee readiness for organizational change at any given time or context is unarguably a positive trait that can reward organizations to prosper in a competitive environment. Such employees, who are in constant readiness to face changes, can be a highly-valued asset to any organization.

Before designing and implementing a change within an organization, the change agents should induce change readiness in the change recipients or the employees. This process requires the change agents to have a prior and comprehensive understanding of the factors that predict change readiness. The importance of this stage and its pervasiveness in change management has turned "change readiness" into a widely discussed topic in the realm of organizational management.

Many scholars, during the past two decades, have had a great interest to investigate for factors associated with employee readiness for organizational change (Armenakis, Harris \& Mossholder, 1993; Cunningham et al., 2002; Madsen Miller, D. \& John, 2005; Miller et al., 2006). However, very little research has been conducted to observe how the factors influential on employee readiness in the developed world apply to developing countries. In an overall, we have a vacuum of academic research in change readiness arena especially regards to business settings in the developing part of Asia (Andrew, 2017; Naotunna \& Arachchige, 2016).

In this article, we investigated the effect of two possible predictors of employee readiness in a developing Asian context. Concretely, we investigated the impact of organizational commitment and trust in peers and management on employee readiness in a business firm in Sri Lanka. In addition, we investigated the effect of employees' demographic factors on their organizational commitment, trust in peers \& management and change readiness. 
Employee Readiness for Organizational Change: A Case Study in an Export Oriented...

For the above purposes, we conducted a case study in an export oriented manufacturing firm in Sri Lanka. This firm was selected for the study as it had been frequently introducing changes to maintain and enhance the firm's productivity. The firm, at the time of this study, was planning to upgrade their manufacturing process and make vital changes in the firm's human resource policy. The study laid its focus on the ground level employees and the shop floor supervisors who represent the largest human resource layer of the firm. To maintain the anonymity of the organization and the respondents, the name of the organization is hereafter denoted by " $X$ ".

\section{Literature review and hypothesis development}

As per the findings of Higgs and Rowlands (2005), 70\% of the change initiatives fail due to different reasons. Some of them are employee related factors and some others are change process related factors (Oreg, 2006). When an organization moves from known to an unknown situation, its employees undergo fear and uncertainty. Shah (2009), who supports this argument, states that an unknown situation could conceive doubt, nervousness and uncertainty in employees. Employees, under such situation, treat change initiatives differently based on their different individual experiences, social characteristics, demographic factors, attitudes, motivational level, perception, behavioral factors and educational level (Ilgen \& Pulakos, 1999). With this regard, open minded employees tend to see at change initiatives positively and consider it as an opportunity to improve. On the contrary, some others may look at it as a threat (Van Dam, Oreg \& Schyns, 2008; Shah, 2009). Employee readiness for change, the dependent variable of this research, explains the degree of openness of the employees for organizational change that transforms the change process into success.

\subsection{Employee readiness}

Holt et al. (2007) identifies readiness to change as the first of the three stages of any successful change process. As defined by Rafferty et al. (2012), readiness for change is the extent to which an individual is cognitively inclined to accept, embrace, and adopt a particular plan to purposefully alter the status quo. Bernerth (2004) defines readiness as the condition of mind during the change process that reveals the acceptance or willingness to participate in the change process. Change recipients' believes, attitudes, thoughts and behaviour regarding the necessity of the change needed and the organisational capacity to achieve it are reflected on their readiness for change (Armenakis et al., 1993; Eby et al., 2000; Bernerth, 2004).

A thorough knowledge in employee change readiness directs the change agents to understand the best way to approach the change and the best mode to implement the change (Soumyaja, Kamlanabhan \& Bhattacharyya, 2015). Susanto (2008) highlights the importance of having better judgment on individual change readiness perception prior to any change implementation. A good assessment of employee change readiness would help change agents, business consultants and 
management to understand the gap between their own expectation about the change and the change recipients' anticipation of the change (Ghany, 2014).

In the change management literature, a number of empirically tested influential factors on employee change readiness can be found. Some of those factors can be listed as, organizational commitment (Eby et al., 2000; Weber \& Weber, 2001; Vakola, Tsaousis \& Nikolaou, 2003; Madsen et al., 2005; Barber, 2010; Vanhala et al., 2016), trust in peers and management (Weber \& Weber, 2001; Rafferty \& Simons, 2006; Oreg et al., 2011; Shah, 2014), change commitment (Herscovitch \& Meyer, 2002; Soumyaja et al., 2015), job satisfaction (Goulet \& Singh, 2002; Robbins, 2003; Shah, 2009; Khammarnia, Ravangard \& Asadi 2014; Lizar \& Mangundjaya, 2014), employee empowerment and social relationship within the organization (Hanpachern et al., 1998; Cunningham et al, 2002; Madsen et al., 2005), support from peers and management (Karasek et al., 1982), teamwork (Rodriguez et al., 2015) and relationship with superiors and peers (Eby et al., 2000; Miller et al., 2006; Barber, 2010; Shah \& Shah, 2010). In this article, we focus on two factors (organizational commitment and trust in peers and management) that have been intensively studied in many developed countries, but hardly in developing countries of their impact on employee readiness.

\subsection{Organizational commitment}

Vanhala et al. (2016) explains organizational commitment as employees' attitudinal commitment towards their organization whereas Madsen et al. (2005) defines organizational commitment as the individuals' attitudes and perception towards the organization. As per Vakola et al. (2003), organizational commitment can be described as employees' desire to make more effort on their organization and their willingness for preserving their bond with the organization. According to Mathews and Shepherd (2002), there are four characteristics of employees who are committed to their organizations; (1) hold strong feelings about the organization's goals and values, (2) have great acceptance on it, (3) willingness to give great effort on behalf of the organization, and (4) willingness to maintain the membership with the organization.

As per Vakola et al. (2003) and Barber (2010), there is a strong positive relationship between organizational commitment and change readiness. Madsen et al. (2005) also reports that employees perceive higher level of change readiness when they are highly committed to their respective organizations. According to Weber and Weber (2001), higher employee involvement in planning and implementing changes could help to decrease the employee resistance for change. Eby et al. (2000) supports the above stance adding that employee participation in change process (a kind of organizational commitment) can increase the employees' openness to change. This active employee involvement or participation in change process is a reflection of employees' organizational commitment. Madsen et al. (2005) lists employee involvement as a constituent of organizational commitment. 
Employee Readiness for Organizational Change: A Case Study in an Export Oriented...

\subsection{Trust in peers and management}

The faith on subordinates and superiors is also an important attitudinal factor that can have an influence on change readiness. Rafferty and Simons, (2006) identifies trust in peers and management as a vital predictor of employee change readiness.

Cunningham et al. (2002) mentions that trust in management is an important precursor in reducing employee resistance for change. Shah (2014), with empirical evidence, states that trust in supervisors and management can act as a catalyst for employees' positive attitudes towards organizational change. Weber and Weber (2001) and Oreg et al. (2011) also found a positive relationship between trust in management and readiness for organizational change. On the other hand, Eby et al. (2000) reports that when employees trust their peers, it can help to reduce their anxieties and make the changed environment comfortable to the employees.

\subsection{Demographic factors}

Shah and Shah (2010) believe demography as a critical factor in organizational behaviour. They could reveal the existence of a significant relationship between readiness for organizational change and demographic variables such as number of dependants and present employment status. Further, the same authors state that the demographic factors can have both positive and negative effects on employee readiness. On the contrary, Madsen et al. (2005) discovers that there are no significant relationships between demographic variables (i.e., age, gender, marital status, job position, number of children and education background) and employee readiness for change. As a similar finding, Cunningham et al. (2002) also discovers that there are no relationships between marital status, gender and openness for change. Further, Hanpachern (1997) finds that age, gender, marital status and education background do not correlate with employee openness for change. In contrast, as per Hanpachem's findings, there are significant relationships between job position, length of employment and employee openness for change.

\subsection{Hypotheses of the study}

To empirically test the relationships between organizational commitment, employee's trust in peers and supervisors and employee readiness, in relation to our study sample, we developed the following hypotheses.

$H_{1}$ : There is a significant positive relationship between employees' organizational commitment and employee readiness for organizational change.

$\mathrm{H}_{2}$ : There is a significant positive relationship between employees' trust in peers and supervisors and employee readiness for institutional change.

Further, as mentioned earlier, this research attempted to investigate the relationships among various demographic factors (gender, age, marital status, education, professional level, and working experience) and the three study 
variables; organizational commitment, trust in peers and supervisors and readiness for change.

\section{Research Method}

\subsection{Sample and data collection}

A cross sectional survey using a self-administered questionnaire was conducted to collect the data. In addition, key informant interviews and group discussions were conducted to collect the primary data. In compliance with the NEA Research Bulletin (1960), a sample of 230 fulltime employees from a work force of 593 employed at the " $X$ " were selected for the survey. The respondents were selected through stratified random sampling. The sample includes 10 executives, 56 supervisors and 164 operational level employees. Even though questionnaires were distributed among 230 employees, only 185 questionnaires were received back and hence the overall respondent rate was $80.4 \%$. The survey was conducted in October 2014.

Most of the respondents were females (58.9\%) whereas $69.6 \%$ of the sample respondents were in the age group of 21-40 years. However, within the operational level employee category, a considerable number of employees $(24.5 \%)$ were less than 21 years old. This indicates a shop floor employee base with fairly a sizeable proportion of amateur employees.

The executive level represented the highest academically qualified employment category of which the half of the population was graduates. Majority of the supervisory level employees had received their education up to G.C.E. Advanced Level $(60 \%)^{1}$. Majority $(51.7 \%)$ of the operational level employees had studied up to G.C.E. Ordinary Level ${ }^{2}$. However, $2.8 \%$ and $2.1 \%$ of the operational level employees had obtained a first degree and professional qualifications respectively. This indicates the under employment of university graduates and other professional qualification holders which has been a hot topic in the country over the past few decades. Employees who had less than 5 years of work experience in this factory were made up of $88.6 \%$ of the respondents. However, most the respondents (86.8\%), including all the executive staff, had experience on organizational change within their current organization. Table 1 summarizes the demographic characteristics of the sample.

\subsection{Instrument and measurement scales}

In this article, the dependant variable was employee readiness for organizational change whereas organizational commitment and trust in peers and management served as independent variables. A two-page questionnaire was used to collect data. The subjective constructs of organizational commitment and trust in peers

\footnotetext{
${ }^{1}$ Final examination of the high school

${ }^{2}$ Final examination of the middle school 
Employee Readiness for Organizational Change: A Case Study in an Export Oriented...

and management and employee readiness were all measured at a five-point Likert scale (1: strongly disagree to 5: strongly agree). The original questionnaire was prepared in English and later translated in to Sinhalese; the native language in Sri Lanka.

Table 1. Demographic characteristics of the sample

\begin{tabular}{llc}
\hline Variable & Category & Percentage \% \\
\hline Gender & Female & 58.9 \\
& Male & 41.1 \\
\hline Age & $<21$ & 19 \\
& $21-40$ & 69.6 \\
& $41-60$ & 11.4 \\
\hline Marital status & Married & 35.1 \\
& Unmarried & 62.7 \\
& Divorced/ widow & 2.2 \\
\hline Educational level & Up to G.C.E. O/L & 41.8 \\
& Up to G.C.E. A/L & 45.1 \\
& Diploma & 6.5 \\
& Graduate & 4.3 \\
& Professional Qualification & 2.2 \\
\hline Professional level & Management/ Executive & 3.2 \\
& Supervisory & 18.0 \\
& Operational & 77.8 \\
\hline Change Experience at the & Yes & 86.9 \\
current organization & No & 13.1 \\
\hline
\end{tabular}

Employee readiness: To measure employee readiness, we developed a nine-item scale based on the previous studies (Madsen et al., 2005; Shah \& Shah, 2010; Shah, 2014). The items of the developed scale are shown in Table 2.

Organizational commitment: Five items were constructed to measure organizational commitment based on the scales developed by Cook and Wall (1980) and thereafter used by Madsen et al. (2005) and Vanhala et al. (2016). Table 2 illustrates all the five items of the latent variable.

Trust in peers \& management: To measure trust in peers \& management, this research used a five-item scale which was constructed based on the scales developed by Brockner et al. (1994), and Nyhan and Marlowe (1997). All the items of this scale are listed in Table 2 with their factor loadings and Cronbach's alpha values.

Demographic factors: The demographic variables were measured as either categorical or scale variables. The categories or measurement units of each demographic variable are shown in Table 1.

\subsection{Data analyses}

At first, we used factor analysis (FA) to determine the factor structure of the items 
and extract common factors. Varimax rotation with Kaiser normalization was performed to elicit the factors while Eigenvalue one test was applied to keep or discard factors. Cronbach's alpha was performed to verify the internal consistency of the study scales. Indices were calculated by averaging items in each scale. To describe the demographic characteristics of the sample, various descriptive statistics such as frequencies, means, and standard deviations were used. Pearson Product-moment Correlation test was used to test the strength and direction of the relationships in above hypotheses. A Multiple Analysis of Variance (MANOVA) was used to analyse the relationship between demographic variables and the three main research variables: organizational commitment, trust in peers \& management and readiness for organizational change.

\section{Results}

\subsection{Initial analysis}

As mentioned earlier, all the items of the three measurement scales were subjected to principal-component analysis for determining the factor structure of each scale. The overall Kaiser-Meyer-Olkin (KMO) measure was 0.814 with individual KMO measures all greater than 0.7. This indicates that the latent constructs could predict the variability in the responses on the observed variables. Bartlett's test of sphericity was statistically significant $(p<0.0005)$, indicating that the data was likely factorizable. The Factor corresponding to change readiness was loaded with six items while organizational commitment and trust in peers \& management were each loaded with five items (Table 2). Cronbach's alpha values extracted for the three major dimensions were above 0.716 (Table 2). As reported by Nunnally (1978), a score above 0.7 is considered reliable, and hence all the scales of this research are reliable.

\subsection{Change experience at the organization}

Figure 1, shows how the employees at the " $X$ " rated their experience on recent organizational change efforts at the firm. All the respondents, those who have experienced change at their current organization, rated their change experience at either successful or very successful levels. The Human resource manager of the " $X$ ", who handles employee grievances, confirmed that his office has not received at least an anonymous employee complaint against the recent change initiatives.

\subsection{Descriptive statistics and Pearson product-movement correlations}

According to the obtained mean score of 4.40 (SD of 0.630 ) for the employee change readiness index on a 5-point Likert scale (1: strongly agree to 5: do not agree at all), a clear majority of the employees at " $X$ " perceive that they are ready to welcome changes in future. The mean scores received for the indices of organizational commitment and trust in peers \& management were 3.65 (SD of 0.630 ) and 3.5 (SD of 0.697 ), respectively (Table 3 ). These mean scores imply that 
Employee Readiness for Organizational Change: A Case Study in an Export Oriented...

employees at " $X$ " perceive moderately high levels of organizational commitment and trust in peers and management.

Table 2. Factor loadings and Cronbach's alpha values

\begin{tabular}{|c|c|c|c|}
\hline Items as in the questionnaire & $\begin{array}{c}\text { Factor } \\
\text { Loadings }\end{array}$ & Communalities & $\begin{array}{c}\text { Cronbach's } \\
\text { alpha }\end{array}$ \\
\hline \multicolumn{4}{|l|}{ Organizational commitment } \\
\hline $\begin{array}{l}\text { If I get another job with the same salary I will not } \\
\text { probably take it }\end{array}$ & 0.621 & 0.393 & \multirow{5}{*}{0.716} \\
\hline I feel proud to be a part of this company & 0.692 & 0.519 & \\
\hline $\begin{array}{l}\text { I get financial and non-financial benefits up to } \\
\text { satisfactory level }\end{array}$ & 0.660 & 0.473 & \\
\hline $\begin{array}{l}\text { Company offers promotions without any discrepancy } \\
\text { at the correct time }\end{array}$ & 0.767 & 0.599 & \\
\hline $\begin{array}{l}\text { Company offers trainings and education relevant to } \\
\text { my job at correct time }\end{array}$ & 0.646 & 0.453 & \\
\hline \multicolumn{4}{|l|}{ Trust in peers \& management } \\
\hline $\begin{array}{l}\text { My colleagues are emotionally ready to implement } \\
\text { changes }\end{array}$ & 0.727 & 0.553 & \multirow{5}{*}{0.785} \\
\hline $\begin{array}{l}\text { When company undergoes turbulence, employees } \\
\text { always try to settle them }\end{array}$ & 0.839 & 0.710 & \\
\hline $\begin{array}{l}\text { I trust management to make decision that are } \\
\text { always good for employees }\end{array}$ & 0.666 & 0.605 & \\
\hline $\begin{array}{l}\text { In turbulent period, employees' ideas and } \\
\text { suggestions are welcome }\end{array}$ & 0.630 & 0.484 & \\
\hline $\begin{array}{l}\text { I trust my colleagues to support me during the } \\
\text { change process }\end{array}$ & 0.621 & 0.471 & \\
\hline \multicolumn{4}{|l|}{ Readiness for organizational change } \\
\hline My willingness to take part in the change process & 0.748 & 0.600 & \multirow{6}{*}{0.838} \\
\hline $\begin{array}{l}\text { My wiliness to support the change process in the } \\
\text { firm }\end{array}$ & 0.716 & 0.579 & \\
\hline My willingness to learn new things & 0.746 & 0.565 & \\
\hline My wiliness to improve my current job position & 0.680 & 0.490 & \\
\hline $\begin{array}{l}\text { My wiliness to take responsibilities of the change } \\
\text { process }\end{array}$ & 0.761 & 0.610 & \\
\hline My wiliness to create new ideas & 0.775 & 0.612 & \\
\hline
\end{tabular}

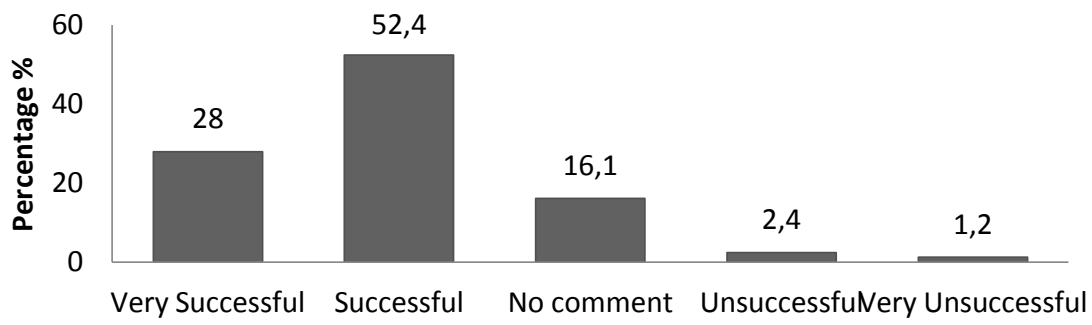

Figure 1. Employee perception on the success of the recent changes 
As shown in Table 3, the correlation analysis showed that employee organizational commitment was linked $\left(r_{s}=0.216, p=0.006\right)$ to employee readiness as predicted by the hypothesis-1 (There is a significant positive relationship between employees' organizational commitment and employee readiness for organizational change). According to Cohen (1988), the strength of an association between two variables is regarded as weak if $r_{s}$ ranges from 0.1 to 0.3 in Pearson correlation test. Therefore, this relationship can be rated as a weak relationship. However, it indicates that higher the perceived commitment to the organization higher the perceived readiness for organizational change

\section{Table 3. Descriptive Statistics and Pearson Product-movement Correlation Test Results}

\begin{tabular}{|c|c|c|c|c|c|c|c|c|c|c|}
\hline Variable & $M$ & SD & 1 & 2 & 3 & 4 & 5 & 6 & 7 & 8 \\
\hline $\begin{array}{l}\text { Employee } \\
\text { readiness for } \\
\text { change }\end{array}$ & 4.40 & 0.630 & & & & & & & & \\
\hline $\begin{array}{l}\text { Organizational } \\
\text { commitment }\end{array}$ & 3.65 & 0.630 & $0.216^{* *}$ & & & & & & & \\
\hline $\begin{array}{l}\text { Trust in peers \& } \\
\text { management }\end{array}$ & 3.50 & 0.697 & $0.338 * *$ & $0.427 * *$ & & & & & & \\
\hline $\mathrm{Age}^{\mathrm{a})}$ & 1.92 & 0.548 & 0.003 & -0.037 & -0.024 & & & & & \\
\hline Marrital status ${ }^{\text {b) }}$ & 1.67 & 0.515 & 0.042 & 0.099 & -0.067 & $-0.244^{* *}$ & & & & \\
\hline $\begin{array}{l}\text { Educational } \\
\text { level }^{\mathrm{c})}\end{array}$ & 1.82 & 0.989 & 0.059 & 0.076 & 0.137 & $0.166^{*}$ & $0.164^{*}$ & & & \\
\hline $\begin{array}{l}\text { Professional } \\
\text { level }^{\text {d) }}\end{array}$ & 2.70 & 0.506 & -0.067 & -0.031 & -0.116 & $-0.228 * *$ & 0.031 & $-0.397 * *$ & & \\
\hline $\begin{array}{l}\text { Workexperienceat } \\
\text { the current } \\
\text { company } \\
\text { (months) }\end{array}$ & 31.20 & 30.87 & -0.080 & -0.007 & 0.016 & 0.148 & -0.062 & -0.075 & $-0.208 * *$ & \\
\hline $\begin{array}{l}\text { Total work } \\
\text { experiences } \\
\text { (months) }\end{array}$ & 65.01 & 48.46 & -0.080 & -0.052 & -0.033 & $0.346 * *$ & $-0.223 * *$ & 0.005 & $-0.229 * *$ & $0.486 * *$ \\
\hline $\begin{array}{l}\text { Notes: } * * \text { corre } \\
\text { (2- tailed), } M=1 \\
\text { a) Age: } 1-<21 y \\
\text { /Widow; c) Edu } \\
\text { qualification; d) }\end{array}$ & $\begin{array}{l}\text { elation i } \\
\text { Mean, S } \\
\text { yrs, } 2 \text { - } 2 \\
\text { ucationa }\end{array}$ & $\begin{array}{l}\text { S signific } \\
\text { SD }=\text { Stan } \\
21-40 y r s \\
\text { al level: }\end{array}$ & $\begin{array}{l}\text { cant at the } \\
\text { ndard Devia } \\
\text { s, 3- 41-60y } \\
\text { 1- Up to O/ }\end{array}$ & $\begin{array}{l}0.01 \text { level } \\
\text { ation. } \\
\text { /rs; b) Marit } \\
\text { /L, 2- Up to }\end{array}$ & $\begin{array}{l}\text { (2- tailed } \\
\text { tal status } \\
\text { A/L, 3- D }\end{array}$ & $\begin{array}{l}\text { * correlat } \\
\text { 1- Marrie } \\
\text { iploma, 4-C }\end{array}$ & $\begin{array}{l}\text { tion is signit } \\
\text { d, } 2 \text { - Unma } \\
\text { Graduate, } 5\end{array}$ & $\begin{array}{l}\text { ficant at the } \\
\text { rried, 3- Div } \\
\text {-Proffesion }\end{array}$ & $\begin{array}{l}\text { e } 0.05 \text { level } \\
\text { vorced } \\
\text { nal }\end{array}$ & \\
\hline
\end{tabular}

As per the results obtained by Pearson Correlation test, a statistically significant, positive and moderate relationship was found between trust in peers \& management and employee readiness for organizational change $\left(r_{\mathrm{s}}=.338, p=0.000\right)$. Thus, hypothesis-2 (There is a significant positive relationship between employees' trust in peers \& supervisors and employee readiness for institutional change) is found to be true and the null hypothesis can be rejected at $p=0.01$. In addition, even though not related to a hypothesis of the research, we found that (Table 3 ) trust in peers \& management was moderately correlated to organizational commitment $\left(r_{\mathrm{s}}=.427, p=0.000\right)$. 
Employee Readiness for Organizational Change: A Case Study in an Export Oriented...

\subsection{Multi analysis of variance (MANOVA) results}

MANOVA was used to analyse the relationship between demographic variables such as gender, age, and so on, and the three main research variables: organizational commitment, trust in peers \& management and readiness for organizational change.

According to the results obtained (Table 4), statistically significant relationships were found between readiness for organizational change and educational level $(p=0.002)$ and readiness for change and total work experience $(p=0.000)$. The other demographic variables were not found directly correlated with employee readiness. In addition, statistically significant relationships were found between trust in peers and management and educational level $(p=0.019)$.

\section{Table 4. Demographic multi analysis of variance (MANOVA) Results}

\begin{tabular}{lcccccc}
\hline Demographic variables & \multicolumn{3}{c}{ Employee readiness } & & \multicolumn{2}{c}{$\begin{array}{c}\text { Organizational } \\
\text { commitment }\end{array}$} \\
& \multicolumn{3}{c}{${ }^{b}$} & & \multicolumn{2}{c}{$\begin{array}{c}\text { Trust in peers \& } \\
\text { supervisors }\end{array}$} \\
\hline & $F$ & $p$ & $F$ & $p$ & $F$ & $p$ \\
\cline { 2 - 7 } Gender & 1.465 & 0.228 & 1.416 & 0.236 & 0.000 & 0.987 \\
Age & 0.082 & 0.921 & 0.147 & 0.863 & 2.030 & 0.135 \\
Marital status & 0.315 & 0.730 & 0.860 & 0.425 & 0.559 & 0.573 \\
Education level & 4.345 & $0.002^{* *}$ & 2.110 & 0.082 & 3.031 & $0.019^{*}$ \\
Professional level & 0.509 & 0.602 & 0.090 & 0.914 & 0.710 & 0.493 \\
Work Ex. at current Org, & 0.920 & 0.588 & 0.811 & 0.739 & 1.074 & 0.380 \\
Total work Ex. & 2.737 & $0.000^{* *}$ & 0.623 & 0.911 & 0.982 & 0.489 \\
\hline
\end{tabular}

Notes: ${ }^{* *}$ correlation is significant at the 0.01 level $(2$ - tailed) * correlation is significant at the 0.05 level (2- tailed), a) $R^{2}=0.001, \Delta R^{2}=0.012$; b) $R^{2}=0.002, \Delta R^{2}=0.011$; c) $R^{2}=0.025, \Delta R^{2}=0.013$. $\mathrm{F}=$ Variance of the group mean, $p=$ probability value, $\mathrm{R}^{2}: \mathrm{R}$ Square, $\Delta \mathrm{R}^{2}=$ Adjusted $\mathrm{R}$ Square

\section{Discussion}

As illustrated in the previous section, this research found a positive and significant relationship between organizational commitment and employee readiness for change. This finding goes in line with the findings of the studies conducted by Eby et al. (2000), Weber and Weber, (2001), Madsen et al. (2005), Vakola and Nikolaou (2005) and Barber (2010). This finding complies with the notion that employees would be more open to organizational change when they are more obligated towards their organization. Therefore, employees' desire to welcome changes could be raised by strengthening the employees' psychological bond with the organization. Effective communication, emotional empowering and reducing uncertainties of the employees can help to strengthen this bond. (Madsen et al., 2005).

The article, as per the second hypothesis, revealed that there is a positive and significant association between trust in peers and management and employee readiness for change. There is a line of similar studies (Eby et al., 2000; Weber \& Weber, 2001; Rafferty \& Simons, 2006; Oreg et al., 2011; Shah, 2014) which 
provides evidence to support our finding. It can be assumed that employees' faith on their peers and the superiors help them to face changes with confidence and certainty as organizational change is more of a team work. On the other hand, as Ajzen (1987) explains in his famous Theory of planned behavior (TPB), human intensions and behaviors are guided by subjective norms. These subjective norms, with regard to an individual, are highly linked to his trust on other individuals who are influential on his behavior.

This article could also reveal that employees' who had faith on peers \& management, were more committed toward the organization. This makes sense that employees' positive faith on their peers and management escalates their commitment towards the organization and vice versa.

Only education and total work experience, among the demographic factors, had a statistically significant positive association with employees' change readiness. The correlation of educational level with employee readiness is supported by previous studies (Hanpachem, 1997; Madsen et al., 2005; Shah \& Shah, 2010). Other demographic factors did not show any degree of correlation with employees' change readiness. Cunningham et al. (2002), Madsen et al. (2005) and Shah and Shah (2010) also discovered that there were no significant relationships between change readiness and demographic variables such as gender, age, marital status, number of years in present job \& number of years with present employer.

Other than that, trust in peers and management correlated with education level $(p=.019)$. In other words, more educated employees showed a higher level of faith on their co-workers and management compared to the employees who had a lower level of education. It can be assumed that formal education train employees to have an open mind that welcomes new and unexpected situations.

\section{Conclusion}

In efforts of organizational change, it is quite difficult or rather impossible to modify or change employees' demographic characteristics as a strategy to achieve a desired change or steer the organization in a direction desired by the organization. However, this article, with reference to a case study in a manufacturing firm in Sri Lanka, reveals that employees' organizational commitment and trust in peers \& management are more influential on their readiness to change over their demographic characteristics. These two factors can be altered through human resource development (HRD) functions such as employee training, employee career development and mentoring. On the other hand, the HRD intervention can also raise the education level of the employees, and hence induce a multiple level impact on boosting employee readiness.

This article concludes that organizational change can still be effectively performed, despite the barriers imposed by undesirable demographic factors, if the organization can formulate a strong and an effective strategy to drive the 
Employee Readiness for Organizational Change: A Case Study in an Export Oriented...

employees' organizational commitment and trust in peers \& management into a very desirable and constructive state.

The results of the change process must be made tangible to employees at all levels, nevertheless the benefits of the change effects must be distributed among all the employees concerned. This can help to sustain the change process through the time. Further studies with bigger and more randomized samples are needed to validate the generalizability of this study. We also encourage research to investigate the impact of other attitudinal factors and their interactive effects on employee readiness for organizational change.

\section{References}

Armenakis, A. A., Harris, S.G. \& Mossholder, K.W. (1993). Creating readiness for organizational change, Human Relations, 46(6), 681-703. https://doi.org/10.1177/001872679304600601

Andrew, A. (2017). Relationship between employee readiness for organizational change and employee performance, Journal for Studies in Management and Planning, 3(1), 23-35. Retrieved from: http://edupediapublications.org/journals/index.php/JSMaP/

Ajzen, I. (1987). Attitudes, traits, and actions: dispositional prediction of behavior in personality and social psychology. In L. Berkowitz (Ed.), Advances in experimental social psychology, 20, 1-63, New York: Academic Press. https://doi.org/10.1016/S00652601(08)60411-6

Barber, V. A. (2010). A study of change readiness: factors that influence the readiness of frontline workers towards a nursing home transformational change initiative. (Education Doctoral Dissertation, St. John Fisher College) Retrieved from http://fisherpub.sjfc.edu/education_etd/36.

Bernerth, J. (2004). Expanding our understanding of the change message, Human Resource Development Review, 3(1), 36-52. https://doi.org/10.1177/1534484303261230

Brockner, J., Konovsky, M., Cooper-Schneider, R., Folger, R., Martin, C., \& Bies, R.J. (1994). Interactive effects of procedural justice and outcome negativity on victims and survivors of job loss. Academy of Management Journal, 37(2), 397-409. https://doi.org/10.2307/256835

Cook, J., \& Wall, T. (1980). New work attitude measures of trust, organizational commitment and personal need non-fulfilment, Journal of Occupational Psychology, 53, 39-52. https://doi.org/10.1111/j.2044-8325.1980.tb00005.x

Cohen, J. (1988). Statistical power analysis for the behavioural sciences (2nd ed.). New York: Psychology Press

Cunningham, C. E., Woodward, C. A., Shannon, H. S., Maclntosh, J., Lendrum, B., Rosenbloom, D., \& Brown, J. (2002). Readiness for organizational change: a longitudinal study of workplace, attitudinal and behavioural correlates, Journal of Occupational and Organizational Psychology, 75, 377-392. Retrieved from http://safewellwork.com/ readiness_for_organizationa.pdf. https://doi.org/10.1348/096317902321119637

Eby, L.T., Adams, D.M., Russell, J.E.A., \& Gaby, S.H. (2000). Perceptions of organizational readiness for change: Factors related to employees' reactions to the implementation of team-based selling, Human Relations, 53(3), 419-442. https://doi.org/10.1177/0018726700533006 
Ghany, M.M.M.A. (2014). Readiness for change, change beliefs and resistance to change of extension personnel in the New Valley Governorate about mobile extension, Annals of agricultural Sciences, 59(2), 297-303. https://doi.org/10.1016/j.aoas.2014.11.019

Goulet, L.R., \& Singh, P. (2002). Career commitment: a re-examination and an extension, Journal of Vocational Behavior, 61(1), 73-91. https://doi.org/10.1006/jvbe.2001.1844

Hanpachern, C. (1997). The extension of the theory of margin: A framework for assessing readiness for change (Doctoral Dissertation). Colorado State University, Fort Collins.

Hanpachern, C., Morgan, G.A. \& Griego, O.V. (1998). An extension of the theory of margin: A framework for assessing readiness for change, Human Resource Development Quarterly, 9(4), 339-350. https://doi.org/10.1002/hrdq.3920090405

Herscovitch, L., \& Meyer, J.P. (2002). Commitment to organizational change: extension of a three-component model, Journal of Applied Psychology, 87(3), 474-487. https://doi.org/10.1037/0021-9010.87.3.474

Higgs, M.J., \& Rowland, D. (2005). All changes great and small: exploring approaches to change and its leadership, Journal of Change Management, 5(2), 121-151. doi:10.1080=14697010500082902

Holt, D.T., Armenakis, A.A., Harris, S.G., \& Feild, H.S. (2007). Toward a comprehensive definition of readiness for change: a review of research and instrumentation, Research in Organizational Change and Development, 16(1), 289-336. doi:10.1016/S0897-3016 (06)16009-7.

Ilgen, D.R., \& Pulakos, E.D. (1999). The changing nature of performance: Implications for staffing, motivation, and development. San Francisco: Jossey-Boss.

Kaiser, H.F. (1974). An index of factorial simplicity, Psychometrika, 39, 32-36. https://doi.org/10.1007/BF02291575

Karasek, R.A., Triantis, K.P., \& Chaudhry, S.S. (1982). Coworker and supervisor support as moderators of associations between task characteristics and mental strain, Journal of Occupational Behavior, 3(2). 181-200. https://doi.org/10.1002/job.4030030205

Khammarnia, M., Ravangard, R., \& Asadi, H. (2014). The relationship of attitudinal empowerment and readiness for organizational changes in health workers, Lorestan, Iran, The Journal of the Pakistan Medical Association, 64(5). 537-541. Retrieved from http://www.jpma.org.pk/PdfDownload/6468.pdf

Lazenby, J.A.A., \& Radebe, K. (2011). Students' perceptions about institutional change at the University of the Free State, African Journal of Business Management, 5(14). 5766-5774. doi:10.5897/AJBM11.747

Lizar, A.A., \& Mangundjaya, W.L.H. (2014). The role of psychological capital and psychological empowerment on individual readiness for change, Proceedings of the Australian Academy of Business and Social Sciences Conference. Retrieved from https://www.aabss.org.au/system/files/published/AABSS2014_236.pdf

Madsen, S.R., Miller, D. \& John, C.R. (2005). Readiness for organizational change: do organizational commitment and social relationships in the workplace make a difference, Human Resource Development Quarterly, 16(2), 213-233. https://doi.org/10.1002/hrdq.1134

Mathews, B.P., \& Shepherd, J.L. (2002). Dimensionality of Cook and Wall's (1980) British Organizational Commitment scale, Journal of Occupational and Organizational Psychology, 75(3), 369-375. https://doi.org/10.1348/096317902320369767 
Employee Readiness for Organizational Change: A Case Study in an Export Oriented...

Miller, D., Madsen, S.R., \& John, C.R. (2006). Readiness for change: implications on employees' relationship with management, job knowledge and skills, and job demands, Journal of Applied Management and Entrepreneurship, 11(1), 3-16. Retrieved from http://works.bepress.com/susan_madsen/31/

Naotunna, S., \& Arachchige, B. (2016). Perceived organizational support and nonmanagerial employees' commitment to change in Sri Lankan apparel firms, South Asian Journal of Human Resources Management, 3(1), 40-57. https://doi.org/10.1177/2322093716637167

Nunnally, J.C. (1978). Psychometric Theory. New York: McGraw-Hill.

Nyhan, R.C., \& Marlowe, H.A. (1997). Development and psychometric properties of the organizational trust inventory, Evaluation Review, 21(5), 614-35. https://doi.org/10.1177/0193841X9702100505

Oreg, S. (2006). Personality, context and resistance to organizational change, European Journal of Work and Organizational Psychology, 15(1), 73-101. doi:10.1080/ 13594320500451247

Oreg, S., Vakola, M., \& Armenakis, A. (2011). Change recipients' reactions to organizational change a 60-year review of quantitative studies, The Journal of Applied Behavioral Science, 47(4), 461-524. https://doi.org/10.1177/0021886310396550

Rafferty, A.E., \& Simons, R.H. (2006). An examination of the antecedents of readiness for fine-tuning and corporate transformation changes, Journal of Business and Psychology, 20(3), 325-350. https://doi.org/10.1007/s10869-005-9013-2

Rafferty, A.E., Jimmieson, N., Armenakis, A. (2012). Change readiness: a multilevel review, Journal of Management, 2(1), 1-26. https://doi.org/10.1177/0149206312457417

Ragadu, S.C. (2008). Change in higher education: perception of female academics at a distance education institution of higher education (Master Thesis, University of Stellenbosch). Retrieved from http://scholar.sun.ac.za/handle/10019.1/2809

Robbins, S.P. (2003). Organizational behaviour: concepts, controversies, application (8th ed.). New Jersey: Prentice-Hall International

Rodriguez, H.P., Chen, X., Martinez, A.E., \& Friedberg, M.W. (2015). An availability of primary care team members can improve teamwork and readiness for change, Health Care Management Review, 41(4), 286-95. https://doi.org/10.1097/HMR.0000000000000082

Shah, N. (2009). Determinants of Employee Readiness for Organizational Change (Doctoral Dissertation. Brunel University). Retrieved from https://core.ac.uk/download/pdf/336930.pdf

Shah, N. (2014). The role of employees' trust in management and supervisors on developing attitudes and behaviours for organisational change, International Journal of Management Sciences, 4(8), 33-342. Retrieved from: https://www.researchgate.net/publication/273921996

Shah, N., \& Shah, S.G. (2010). Relationships between employee readiness for organizational change, supervisor and peer relations and demography, Journal of Enterprise Information Management, 23(5), 640-652. https://doi.org/10.1108/17410391011083074

Soumyaja, D., Kamlanabhan, T.J., Bhattacharyya, S. (2015). Antecedents of employee readiness for change: mediating effect of commitment to change, Management Studies and Economic Systems, 2(1), 11-25. Retrieved from http://www.msaes.org/article_10100_8cab370b17a42ce3948ef58d02d2f9be.pdf. 
Susanto, A.B. (2008). Organizational readiness for change: a case study on change readiness in a manufacturing company in Indonesia, International Journal of Management Perspectives, 2(1), 50-61. https://doi.org/10.1002/ceat.200800457

Vakola, M., Tsaousis, I., \& Nikolaou, I. (2003). The role of emotional intelligence and personality variables on attitudes towards organizational change, Journal of Managerial Psychology, 19. 88-110. https://doi.org/10.1108/02683940410526082

Van Dam, K., Oreg, S., \& Schyns, B. (2008). Daily work contexts and resistance to organizational change: The role of leader-member exchange, development climate and change process characteristics, Journal of Applied Psychology, 57(2), 313-334. https://doi.org/10.1111/j.1464-0597.2007.00311.x

Vanhala, M., Heilmann, P., \& Salminen, H. (2016). Organizational trust dimensions as antecedents of organizational commitment, Knowledge and Process Management, 23(1). 4661. https://doi.org/10.1002/kpm.1497

Weber, P.S., \& Weber, J.E. (2001). Changes in employee perceptions during organizational change, Leadership and Organization Development Journal, 22(6), 291-300. https://doi.org/10.1108/01437730110403222 